\title{
The Land of Opportunity Doesn't Apply to Everyone: The Immigrant Experience, Race, and Asian American Career Choices
}

\author{
OiYan Poon \\ Loyola University Chicago, opoon@luc.edu
}

Follow this and additional works at: https://ecommons.luc.edu/education_facpubs

Part of the Education Commons

\section{Recommended Citation}

OiYan Poon. "'The Land of Opportunity Doesn't Apply to Everyone": The Immigrant Experience, Race, and Asian American Career Choices." Journal of College Student Development 55, no. 6 (2014): 499-514.

This Article is brought to you for free and open access by the Faculty Publications and Other Works by Department at Loyola eCommons. It has been accepted for inclusion in Education: School of Education Faculty Publications and Other Works by an authorized administrator of Loyola eCommons. For more information, please contact ecommons@luc.edu.

\section{cc) (†) $\ominus$}

This work is licensed under a Creative Commons Attribution-Noncommercial-No Derivative Works 3.0 License. (C) 2014 American College Personnel Association (ACPA). 


\section{"The Land of Opportunity Doesn't Apply to Everyone": The Immigrant Experience, Race, and Asian American Career Choices}

\section{OiYan Poon}

Despite their popular portrayal as high achieving and structurally incorporated, race continues to shape the career choices of Asian American college students. As second-generation Americans, Asian Americans negotiate a constellation of factors when deciding their career choices, most notably, pressures from immigrant parents, awareness of labor market discrimination, fear of being tokenized in particular occupational fields, and influences from peer networks. These findings help elucidate how race and the social context of immigrant adaptation can affect the occupational trajectories of Asian Americans and other children of immigrants in the United States, regardless of their educational achievement and socioeconomic status.

Asian Americans are a diverse population inclusive of persons with ethnic origins in East Asia, Southeast Asia, the Indian subcontinent, and the Philippines. ${ }^{*}$ They represent the fastest growing racial group segment of the undergraduate population in the United States (Chang, Park, Lin, Poon, \& Nakanishi, 2007) but only about $6 \%$ of college students nationally (Teranishi, 2010). Despite the growth, there remains little research illuminating their college experiences and implications for student affairs practice. Without such research, student services practitioners and institutional leaders can be unconsciously guided by stereotypes in how they work with this socioeconomically diverse population (McEwen, Kodama, Alvarez, Lee, \& Liang, 2002; Museus \& Kiang, 2009). Prevailing images of Asian Americans as monolithically successful may lead to assumptions that these students require less support than others, even though many are first-generation college students from lowincome and immigrant or refugee families (Chang et al., 2007; Suzuki, 2002; Yeh, 2002).

The study presented in this article contributes to scholarship on Asian American college students by focusing on career development experiences and contexts of second-generation Asian Americans in college. Throughout this article, I use the terms second generation, immigrant second generation, and new immigrant second generation interchangeably in reference to both U.S.-born children of immigrants (i.e., second-generation Americans) and immigrants who arrived in the United States as young children (i.e., 1.5 generation). New immigrant second generation is a term coined by sociologists who study the experiences of post-1965 immigrants to the United States (Portes \& Rumbaut, 2001). Although not all Asian Americans identify as second generation, growing up in immigrant families is common among a great majority of Asian American college students. For example, $95 \%$ of Asian

* I do not include Native Hawaiians and other Pacific Islanders (NHOPI) in this study due to the socio-historical differences between the racialization of Pacific Islanders and Asian Americans. For a more detailed discussion about the problematic nature of the "Asian Pacific Islander," "Asian Pacific American," or "Asian American and Pacific Islander" terms and category, please read Dr. J. Kehaulani Kauanui’s (2008) commentary.

OiYan A. Poon is Assistant Professor in Higher Education at the Loyola University Chicago School of Education. 


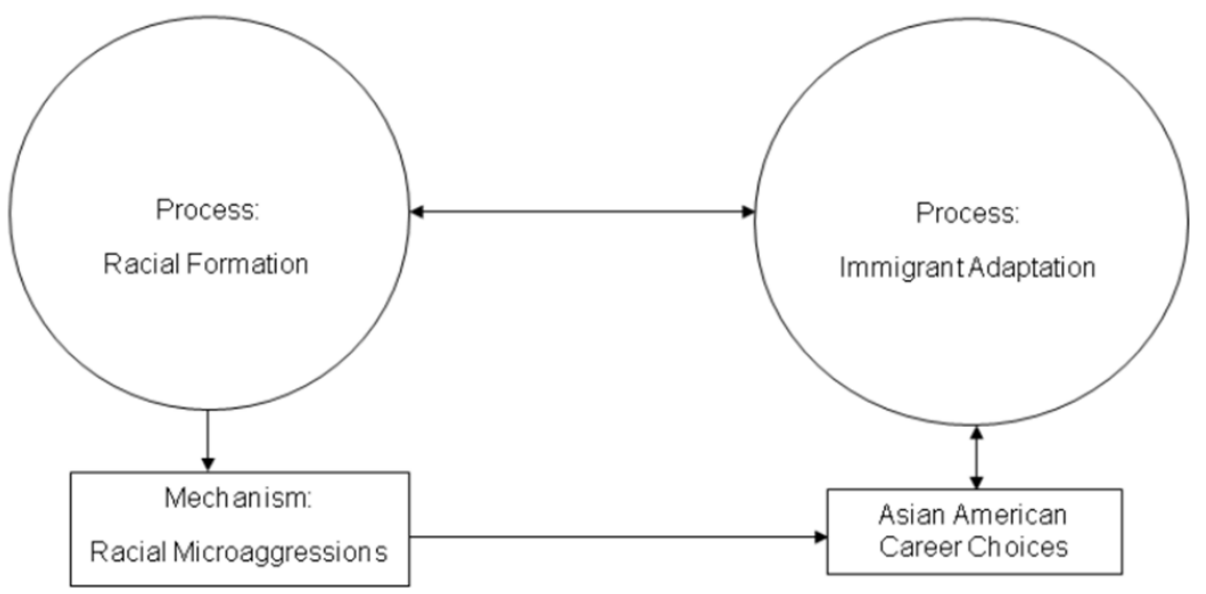

Figure 1. Conceptual Framework

American undergraduates in the University of California system identify as having an immigrant parent (Brint, Douglass, Flacks, Thomson, \& Chatman, 2007).

The analysis in this article emerged from a larger study that examined Asian American college students' experiences with racial microaggressions, which are daily experiences of subtle discrimination and racist assaults experienced by people of color that socially maintain their racially subordinated position and White racial power in society (Solórzano, 1998). Through the course of the original study, several students discussed how racial microaggressions influenced their vocational decisions. During the initial analysis of data, the emergent theme of vocational choice was deemed worthy of further exploration.

A wide range of influences, including socioeconomic background, identity, decisionmaking approaches, and interpersonal interactions, has been found to shape college students' career decisions (Brown, 2004). However, limited student development scholarship has explored vocational choice contexts of Asian American college students or students from immigrant families. Because the majority of Asian American college students identify as second generation, this study contributes to literature on collegiate experiences of the new second generation. Accordingly, this study was guided by the primary research question: How might Asian American students' status as children of immigrants and racial minorities influence their vocational outlook and career choices?

In the next section, I present a conceptual framework to account for the intersectionality of race and immigrant community context experienced by Asian American college students. Because there is little research on Asian American career development, the literature review section draws from the field of occupational psychology. The study background and methods is then summarized. Following the summary of results, the article concludes with a discussion of study limitations, implications for student services practice, and ideas for future research directions.

\section{Conceptual Framework}

The conceptual framework (Figure 1) depicts the relationship between the processes of immigrant adaptation and racial formation and how they respectively contextualize and shape Asian American career choices through racial microaggressions. Historically, U.S. immigration policies have been rooted in racial 
projects that continuously transform social meanings of race (Omi \& Winant, 1994). Conversely, the ways in which immigrant populations have utilized their agency to confront and adapt to socioeconomic, cultural, and political terrains in the United States have the power to also reshape racial meanings (Kim, 1999; Lowe, 1996). Career choices represent individual acts within the context of the immigrant adaptation process and are potentially influenced by racial microaggressions, which are tangible mechanisms through which the process of racial formation is enacted. The remainder of this section discusses the pieces of the conceptual framework for this article.

\section{Racial Microaggressions as Tangible Embodiment of Racial Formation}

This article draws from data and analysis from a larger qualitative study on Asian American college students' experiences with race conducted using a critical race theory (CRT) lens. Yosso (2006) described the five tenets of CRT in education as the intercentricity of race and racism, the challenge to dominant ideology, the commitment to social justice, the centrality of experiential knowledge, and the interdisciplinary perspective. CRT provides a scholarly approach to articulate the ways in which race intersects with other social identities to structure people's experiences. The original study aimed to understand whether and how Asian American college students experienced racial marginalization through racial microaggressions on a campus with an Asian American plurality in undergraduate enrollment. By focusing on student experiences with racial microaggressions, scholars can "better understand how campus racial climate affects the educational experiences and outcomes of Students of Color" (Solórzano, Allen, \& Carroll, 2002, p. 16). Therefore, students were invited to share narratives of their experiences confronting any racial microaggressions, which are subtle albeit oppressive, interpersonal experiences that serve to maintain social hierarchies and inequalities.

Additionally, by examining racialized interpersonal interactions in the form of racial microaggressions, the process of racial formation, which is "the sociohistorical process by which racial categories are created, inhabited, transformed, and destroyed" (Omi \& Winant, 1994, p. 55), can be better understood. By defining racial categories within a social context, the process of racial formation also serves to continuously transform racial meanings that organize social relations. Incidents of racial microaggressions can be viewed as a type of racial project, which serves to "connect what race means in a particular discursive practice and the ways in which both social structures and everyday experiences are racially organized, based on that meaning" (Omi \& Winant, 1994, p. 56). Therefore, the process of racial formation produces racial meanings, inequalities, and conflict through the perceptible mechanism of racial microaggressions.

In addition to highlighting Asian American student experiences with racial microaggressions, analysis from the previous study pointed to the importance of students' identities as children of immigrants. Therefore, the analysis in this article stems from a conceptual framework that acknowledges the ways in which intersectional student identities as racial minorities and children of immigrants can simultaneously work to influence Asian American college students' career choices.

\section{The Immigrant Community Context and Career Choices}

Dramatic changes in U.S. immigration policies since the late 1800s have resulted in significant growth and unique socioeconomic patterns, including occupational status, found in the 
Asian American population. In 1882, antiAsian immigration laws restricted the migration of Asians to the United States (Chan, 1991). In 1965, the Immigration and Nationality Act liberalized policy and drastically diversified the racial makeup of immigrants in the United States (Hing, 2004). The new law resulted in a new immigrant majority among the Asian American population. It also created a system that privileged primarily highly educated immigrants with professional skills, especially in the sciences, engineering, health, and medical fields and, secondly, welcomed individuals with family ties in the United States as well as war refugees (Ong \& Liu, 1994). Many refugees and those immigrating to reunite with family possessed less economic, social, and human capital than did those who arrived with professional and technical skills (Hing, 2004). Consequently, by the 1980 s the Asian American population consisted of both formally educated, professional class members, who were highly concentrated in a handful of professional fields, and working class individuals, who were often pressed into the ethnic enclave economy (Takaki, 1989).

To understand the dramatic demographic shifts resulting from immigration policy changes, a revival of scholarship on immigrant assimilation, adaptation, and incorporation into has emerged (Portes \& Rumbaut, 2006). Accounting for the experiences of the 1.5and second-generation American children of immigrants, some scholars have examined and identified diverse ways in which those of the new second generation have been navigating and been incorporated into U.S. social structures and institutions such as education and the labor markets (Portes \& Rumbaut, 2001). Generally, this scholarly canon is concerned with macro-level measures of socioeconomic assimilation among transnational migrants and their progeny (Portes \& Fernández-Kelly, 2008). An important limitation in this research is that attention to immigrant adaptation and its effects at the micro, individual, or family levels has been scant (Park, 2005).

Therefore, this article offers a theoretical intervention by framing career choice processes and decisions as an important aspect of immigrant adaptation for second-generation Asian Americans. Research on the vocational choices of Asian American college students can lead to more complex insights into how this particular segment of the new immigrant second generation is adapting to U.S. socioeconomic structures. As SuárezOrozco and Suárez-Orozco (2001) have stated, "the future character of American society and economy will be intimately related to the adaptations of the children of today's immigrants" (p. 3).

\section{LITERATURE REVIEW: CAREER DEVELOPMENT AND ASIAN AMERICANS}

In the literature on career development, Holland's theory of careers serves as a foundation for research and practice in college student career development (Evans, Forney, \& GuidoDiBrito, 1998). According to Holland (1997), vocational fit depends on the interaction between personality types, vocational interests, and work environments. The individualistic orientation of Holland's framework (Feldman, Smart, \& Ethington, 2004) can present a limitation to understanding Asian American student experiences. Asian American college students have been found to be more influenced by external, social factors than by internal and individual motivations in their development (Kodama, McEwen, Liang, \& Lee, 2001).

Accounting for the influence of social factors, scholars in the field of occupational psychology have identified several external variables that affect vocational self-efficacy and, consequently, Asian American career choices. 
Self-efficacy or "an individual's confidence is shaped by his/her contextual factors such as ethnicity, age, gender, support system, and past learning experiences" (Tang, Fouad, \& Smith, 1999, pp. 143-144). Pointing to the significance of acculturation, identity, and families, this literature emphasizes the important context of the immigrant incorporation process.

Overall, research has found that acculturation can be a mediating factor influencing levels of self-efficacy and perceived discrimination among Asian Americans in their career choice outlook. The range of career choice options can be limited by lower levels of self-efficacy among less acculturated Asian Americans (Tang et al., 1999) and by family expectations (Leong, Kao, \& Lee, 2004). More acculturated Asian Americans have also been found to be less likely to be impacted by family opinions and more likely to choose atypical career paths than are less acculturated, co-ethnic peers (Leong \& Chou, 1994). For the purposes of this article, atypical Asian American career choices are occupations that are not perceived to garner financial rewards and do not include STEM-related or business-related career paths, in which there is a high concentration of Asian Americans. Self-efficacy among Asian American adolescents can also be mediated by peer networks that can provide encouragement for more confidence in career decisions (Patel, Salahuddin, \& O’Brien, 2008). Additionally, research has found that Asian American acculturation is positively correlated with perceived discrimination, which in turn can limit career choice possibilities to more common occupational fields (Roysircar, Carey, \& Koroma, 2010).

The research on Asian American career development has recognized the importance of external factors, clearly focusing on the immigrant experience of acculturation as a central concern. It has emphasized the mediating role of acculturation in shaping self-efficacy, perceived discrimination, the influence of family and peers, and financial concerns in Asian American career choice. Although newer research has suggested that discrimination plays a role in limiting Asian American career choices, most of the extant research has framed discriminatory experiences as outcomes of acculturation, therefore, privileging immigrant acculturation over racialized experiences.

This article reveals how career development for second-generation Asian Americans can be shaped by intersectionality in their identities as students of color and as children of immigrants. It provides a closer look at the complex social context within which Asian American students make career choices. It also contributes to the knowledge about how one segment of the new immigrant second generation is preparing to participate in the workforce and thus adapting to U.S. socioeconomic structures as new Americans.

\section{STUDY BACKGROUND AND METHOD}

This section describes the methods undertaken for recruitment, data collection, and analysis. The exploration of Asian American career choices presented drew from a larger qualitative study that examined the experiences of 25 Asian American undergraduates with campus racial climate at a large public research university on the West coast, referred to as Coastal University throughout the article. Students were asked to describe any experiences encountering racial microaggressions as students at Coastal. Many discussed social interactions that demarcated suitable academic and vocational opportunities for Asian Americans. Therefore, the results of the previous study warranted further exploration. 
TABLE 1.

Characteristics of 25 Interview Participants

\begin{tabular}{|c|c|c|c|c|c|}
\hline Characteristic & East Asian & South Asian & $\begin{array}{c}\text { Southeast } \\
\text { Asian }\end{array}$ & Filipino & Total \\
\hline Ethnicity ${ }^{a}$ & 12 & 2 & 7 & 4 & 25 \\
\hline \multicolumn{6}{|l|}{ Gender } \\
\hline Female & 6 & 2 & 3 & 3 & 14 \\
\hline Male & 6 & - & 4 & 1 & 11 \\
\hline \multicolumn{6}{|l|}{ Academic major } \\
\hline STEM & 2 & - & 3 & 2 & 7 \\
\hline Humanities/Social Sciences & 9 & 2 & - & 2 & 13 \\
\hline Business & 1 & - & 1 & - & 2 \\
\hline Undeclared & - & - & 3 & - & 3 \\
\hline \multicolumn{6}{|l|}{ Generational status } \\
\hline 1.5 generation & 4 & - & 1 & - & 5 \\
\hline Second generation & 8 & 2 & 6 & 4 & 20 \\
\hline
\end{tabular}

a "East Asian" includes Chinese, Korean, Japanese, and Taiwanese. "South Asian" includes individuals who identify as having ethnic and national origins in the Indian subcontinent. "Southeast Asian" includes those who ethnically identify as Cambodian or Khmer, Hmong, Laotian, Thai, or Vietnamese. Each of these categories, in addition to "Filipino," is used to represent subgroups within the larger Asian American panethnicity.

\section{Study Site and Participants}

At the time of the study in 2008 , there were over 25,000 undergraduate students enrolled at Coastal University, of which $38 \%$ were Asian American, 33\% were White, 15\% were Chicano or Latino, and $4 \%$ were African American. The remaining 10\% identified as American Indian, international students, or declined to state their race or ethnicity. To recruit students, I used a purposeful sampling strategy (Patton, 2002) to target potential participants who identified as 1.5- or secondgeneration Asian American. I distributed over 500 flyers to any student who I thought looked Asian American in and around the central Student Union building over a 2-week period in the Fall 2008 academic term. The flyers invited students who identified as 1.5or second-generation Asian American and had at least sophomore standing to complete an online survey, which asked for simple demographic information including ethnicity, gender, generational identity, economic class, academic standing, and major. The survey was used to verify whether a student fit the study's criteria and to collect contact information of students to invite for interviews. Fifty-one out of 52 survey respondents fit the study's criteria and were sent an e-mail invitation to schedule individual interviews. Interviews were ultimately arranged and completed with 25 students.

Interview participant characteristics are summarized by academic major, ethnicity, gender, and immigrant generation in Table 1 . The students in this study were less likely than the overall population of Asian American undergraduates at Coastal to be pursuing STEM majors. Institutional data at the time of the study indicated that Asian American 
students were the most likely (58\%) to pursue STEM majors. In comparison, only $39 \%$ of White students, 38\% of African American students, and $38 \%$ of Latino students were STEM majors. Interestingly, the distribution of majors for Asian Americans at Coastal University was very similar to that of international students, of whom 55\% were STEM majors.

\section{Qualitative Data Collection and Analysis}

This study aimed to identify ways in which Asian American vocational choices transpire at the intersection of their identities as children of immigrants and as students of color. Qualitative data were collected through individual semi-structured interviews, which were conducted in a private office at Coastal University. Each interview lasted between 1 and 2 hours.

Both personal and professional experiences informed the research design and interpretation of results. As a second-generation Asian American, I shared aspects of my identity with the research participants. Moreover, I had spent several years working as a student affairs professional in programs targeting Asian American and Pacific Islander students. According to Delgado Bernal (1998), a researcher's racial identity and past professional experiences contributes to cultural intuition, which can be an important asset in conducting research. The concept of cultural intuition extends Strauss and Corbin's notion of theoretical sensitivity, which consists of one's personal and professional experiences, existing literature, and the research process, to include collective community memory (Delgado Bernal, 1998).

Based on cultural intuition, I developed an interview protocol mindful of potential discomfort that might be elicited for students in a conversation about anti-Asian racism. I started interviews by explaining that my study was interested in Asian American student experiences with racial microaggressions, and I presented interview participants with a onepage handout that provided a definition of racial microaggressions and themes, as summarized by Sue, Bucceri, Lin, Nadal, and Torino (2007), that might affect the lived experiences of Asian Americans. After giving students some time to read through the handout, I discussed the definition of racial microaggressions with each student to establish a common understanding of the concept. I then asked, "Can you tell me what you think of this theory and these categories of microaggressions?" After engaging in an initially academic conversation of racial microaggressions, interview participants were asked, "Have you experienced racial microaggressions at Coastal University?" which allowed students the opportunity to share narratives of their personal experiences that contested, confirmed, and expanded on the themes.

To establish trustworthiness of data, a process of member checking and extensive documentation of the study was provided for an audit trail and review by a committee (Creswell \& Miller, 2000). During the interviews, I summarized and mirrored students' responses and narratives to verify meanings and to encourage students to provide more detail in their narratives. Following the transcription of interviews, participants were provided with transcripts for review. Throughout the study, a committee of respected education scholars reviewed the accounts of the study's procedures, analysis, and development of findings.

Interview data were coded using a grounded theory strategy to generate emergent conceptual categories from the analysis of data (Glaser, 2002). During the interviews, many participants shared stories about experiences of racial microaggressions and 
other social interactions that informed their vocational choices. These narratives were elicited by discussions about the "ascription of intelligence" theme identified by Sue and colleagues (2007). The handout summarized the description of this theme as follows:

This is the assumption that "all Asians are math and/or science geniuses" simply based on race. An example on campus might be when someone might say, "I'm not taking that class. Most of the room was full of curve-busting Asian kids." Experiences under this theme may make Asian Americans feel pressured to conform to the stereotype, or even trapped by it. The message conveyed is that to be Asian American means being a genius who never experience academic challenges or difficulties.

Because this description and category is not explicitly connected to occupational choices, data on microaggressions affecting career choice considerations were not anticipated. However over half of the participants discussed career choices during their interviews, justifying a more thorough reflection on the results related to career choices, as presented in the next section.

\section{RESULTS}

Fourteen of the 25 interviewed students discussed or mentioned how social interactions related to Asian American career choices. Nine were pursuing atypical academic or career paths. Talking about racial microaggressions did not elicit discussions about career choices for the remaining 11 interview participants, of whom seven identified as STEM majors. Thus, students experiencing conflict between expectations and personal interests in career choices were more likely to bring up the topic of vocational pathways.

Overall, the analysis of data revealed one major and three secondary themes related to vocational outlook and choices. Family desires represented a major theme. The three secondary themes were perceived labor market inequalities, racial isolation in atypical fields, and peer networks and social discipline. The four themes encouraged the pursuit of familiar STEM-related and business-related careers among the Asian American respondents in this study through both positive and negative social reinforcement. They indicated the ways in which some Asian American college students' career choices can be influenced by their identities as racial minorities and children of immigrants.

\section{Family Desires and Career Choice}

Consistent with extant research on Asian American career development, family played an important role in some participants' perceptions of vocational paths. Eleven interviewees mentioned talking with parents or other relatives about career paths, but only two had chosen to conform to family expectations. Another three were unclear about their paths. The rest had chosen to follow their personal interests, but were mindfully navigating and countering family expectations. Some family elders, all of whom were immigrants or refugees, encouraged students to pursue academic majors and vocational paths that were familiar and proven means to them of achieving economic and social status stability.

For example, Seung, a 1.5-generation Korean American male studying communications, suggested that his family was interested in economic and social gains that a STEM career might bring:

I was born in Korea, and came to the U.S. when I was two years old. So I guess they wanted me to live the American life - money and get rich and respect, and to gain respect in the family and make money. They thought being doctors and being engineers or something would help you achieve it. 
Seung's comments indicated the important role of career choice in gaining financial and social status within the process of immigrant adaptation and efforts to gain upward mobility as an immigrant family.

Walter, a 1.5-generation Chinese American engineering major, who had a passion for his chosen STEM academic and vocational pathway, noticed many of his Asian American peers in STEM majors who were not interested in science and math. He believed that many were strongly influenced by their immigrant parents to pursue their majors, which were perceived to result in financial gains:

In the eyes of Asian parents, they work so hard to get here. They want their children to be successful. [Author: What does successful mean?] Financially well off. So they push them to be engineers ... lawyers ... . well not lawyers because that's more North campus [where social science and humanities departments are located at Coastal University]. Doctors, pre-health professions . . . even like finance because you need a strong background in math. Not every Asian is into math and science, but they still want to please their parents. So they go into [economics] or applied math if they don't do science.

Walter could have been describing Raakhi's experiences even though she was not being influenced into pursuing a major in a STEM field. Despite her interest in politics and a successful Congressional internship, Raakhi, a second-generation Indian American woman, had chosen to follow her father's desires for her to pursue a financial career. Her choice was reinforced by her desire to avoid the conflict her older sister had experienced, as she explained:

My sister's pre-med, and she wanted to do journalism. Her getting into med school was the hardest thing for our family. It was so much drama. She didn't get in the first time, and you have to wait a year. That year was hell on earth. She was like, "I wanted to do journalism. You didn't let me!" I think because my parents were really poor growing up. They really want us to be financially successful.

Raakhi conjectured that her parents' desires for her and her older sister to pursue specific vocational pathways for financial gain were related to her parent's experiences with poverty prior to immigrating to the United States.

Unlike Raakhi, Amber, a second-generation Chinese American, directly experienced conflict in her family over her academic and career choices. She was completing her political science and ethnic studies double major and had recently applied to masters programs in social work. Amber shared:

When I told my mom I was really interested in political science and Asian American Studies, she basically said, "What's that?" And I had a very difficult time explaining, and even as I'm applying for grad school in social welfare, she doesn't understand the humanities and what that offers. I think she really cares about "What's the bottom line? What will get you the job?" She always taught all of us to believe that the sciences, that's what you should be good at. In my own family, it's been a struggle because I was always viewed as the dumb one because I was the youngest, and I was a girl, and my math and science was definitely not to the level of my brothers.

For Amber, her mother's disapproval of her vocational path caused her some emotional pain. However, Amber also believed she understood her mother's perspective:

I think economic stability is a priority for her. I think it's because we grew up and we weren't financially stable. So I think with her pushing us toward those fields, it's more seen as economic stability because you can be guaranteed a specific income. 
I think that's how she defines stability, and I think that's the reason why; she wants us to not suffer.

Like Amber, most of the students who mentioned family interactions that communicated what acceptable and unacceptable occupations followed their interests anyway. For example, Jestine, a second-generation Chinese American studying film shared:

At first, [my parents] really opposed it. I was supposed to go to [San Diego] for biology. I couldn't do it. I even went through orientation. So in the end, I decided I can't do something I don't love, and because I won't be successful. My mom flipped out.

Jestine abruptly changed her plans to pursue her passion in film and deal with the familial consequences. Other students navigated family expectations with less conflict. Seung's parents wanted him to become a doctor, but as he explained:

I didn't want to go into math or science for sure. So I came in undeclared, but I like film. The communications major kind of deals with film and stuff too. So it was like another major you could go through. And it's kind of competitive here too, so you can tell your parents, "It's competitive to get in." So then when I explained the competitive nature of the department, and that I got into the major, my parents were proud of me.

Although many shared that their relatives had communicated their interests, only two followed their parents' expectations. Moreover, one explained that career choice conversations with her immigrant parents were not laden with expectations. Chunhei, a second-generation Korean American female studying psychology, explained, "[My parents] never pushed me to a career. They just wanted me to have some stability. Both of them said, 'You can do whatever you want." Even though few followed their families' career interests for them, testimonies demonstrated students' consciousness of their immigrant family desires. They also showed that Asian American college students can navigate these expectations in different ways.

\section{Perceived Labor Market Inequalities}

Seven interview participants discussed how their perceptions of racial inequalities in the labor market and stereotypes played roles in hindering them from pursuing their career interests. Moreover, some interview participants were aware of racial disadvantages and barriers in their fields of interest. For example, Seung explained:

Because I'm really into film and editing and stuff like that, it'll be harder for me to go into that industry than for other people. Even in like music, it's harder for us, for an Asian person to go into. Asians are only good for engineering, things like that, sciences and math. But when it comes to those other industries like music and film and anything else, it seems harder for them. I think it draws people away from saying like, "I want to go into that career," to "I'll just make it a hobby."

Like Seung, Jason, a second-generation Taiwanese American male studying psychobiology and arts, was also interested in pursuing a career in the entertainment industry and reflected on the lack of Asian Americans in these fields:

I thought about the lack of Asian Americans in the arts the other day. I don't know any Asian bands. There's like Linkin Park. And in the film industry, all I can think of is George Takei or Bobby Lee or like John Cho and Harold and Kumar. I try to think of why, and I think people don't think it's a possible career choice.

Ruth, a second-generation Chinese American torn between her interests in the 
arts and familial expectations of a healthrelated career, shared:

The idea of the U.S. being the land of opportunity doesn't apply to everyone in all fields. I feel like Asians, and this is another stereotype, at least from my upbringing, and I see it's true ... Asians really ascribe a lot of value to being set or stable. Math and science, engineering, medicine, law, those things are really stable, clear cut. You know you can do well, but to take a big risk on things like art, it's . . . and I don't see a lot of Asian parents encouraging their children to pursue their interests. It's not safe.

For Ruth, safety along one's career path may be found in STEM fields and other occupations that are perceived to provide financial security and a level of social status security.

\section{Racial Isolation in Atypical Fields}

Five interview participants interested in pursuing atypical academic majors or vocational pathways explained that some experiences were characterized by feelings of racial isolation as one of the few or only Asian Americans in their field. Although nearly $40 \%$ of the undergraduates at Coastal were Asian American, $58 \%$ of them majored in STEM fields, spatially locating them primarily on the south end of campus. With $42 \%$ pursuing degrees in nonSTEM fields, Asian Americans represented about $17 \%$ of students on North campus. For some students, these relatively lower numbers of Asian Americans on North campus led to feelings of being the only one or one of the few Asian Americans in their classrooms. For example, Shirley, a second-generation Filipina studying comparative literature, noted:

It's just really interesting how even in my Latin classes I noticed I'm the only Asian there. Maybe the one other random Asian there, they're only there because they're pre-med and they want to learn the terms. It's very strange. But then literature and especially Latin class - most everyone else, they were like White. Most of [the White students] were either Classics or English literature people. So it was like, you're kind of related to my field, but they're not. I don't feel connected to them.

Likewise, Jill observed that she knew very few Asian Americans majoring in the social sciences or humanities. She commented, "A lot of my Asian American friends are science majors or business majors. I only know three Asian Americans, including my brother, who are North campus." As a fine arts major, Jill's brother, Wilson, who was also interviewed for the study, remarked on his experiences of being one of the only non-White undergraduates in his academic department. He stated, "In the art department, it's mostly Caucasian. I think the art department is also mostly female. The professors are all Caucasian, and the students are mostly Caucasian. So it's kind of awkward for me sometimes."

In addition to knowing few other Asian Americans in the social sciences or humanities, Jill noted that the lack of role models also affected her vocational decision-making process. Although she was interested in being an interior designer, Jill stated, "I don't think I can make a living with that because I've never met [an Asian American interior designer] before and I don't know how they do. My parents are worried about if I'm going to make money." Thus, Jill's perception of career possibilities was also influenced by an observed lack of role models.

\section{Peer Networks}

Four of the study participants mentioned peer networks playing a role in reinforcing the idea that Asian Americans belong in certain fields and not in others. Wilson discussed how some of his Asian American friends who were STEM majors questioned his choice to study and pursue a career in the arts: 
The more frustrating part for me was they're like, "South campus is better than North campus." If you're on North campus it means you're not smart. That's frustrating because I did well in a lot of subjects in high school. For people to say that you're not good at math or physics, it's just frustrating because they say, "We're on South campus, we're smarter," and it mostly comes from other Asian people. It's just frustrating. It's more an offense toward my intelligence and less about my Asian identity.

Likewise, Seung encountered classmates who questioned his decision to be a communications major, explaining, "I guess a lot of times, people will ask what my major is, and they're like, 'Oh really? Not South campus? Not premed?' And things like that." For Seung, his interactions communicated that it was out of the ordinary for him to not be a STEM major.

Although peer networks seemed to negatively reinforce the idea that Asian Americans belonged in certain fields for Wilson and Seung, Tasanee suggested that her social network provided positive reinforcement for Asian Americans to pursue careers in STEM and other fields perceived to be financially lucrative. A second-generation Thai American studying business, Tasanee stated:

I think a lot of Asians are going into accounting and like tax jobs, like in my major. I have a lot of friends who are doing audit tax because it's a very secure stable job, and at my internship over the summer at an accounting firm a lot of the people were heavily Asian as well.

As a business major, Tasanee shared that she did not experience social isolation and marginalization for her academic choice, but she did empathize with a friend who experienced significant difficulties:

I had a friend who was a music major. She's Korean, and her twin brother is very smart, loves math, was bio, pre-dental. She always told me it was hard in her family because she felt like an outcast because music wasn't something a lot of Asian parents specifically want their children to do. She used to complain to me a lot, and she goes to Cal State for music. It's a very good program. She doesn't like that a lot of people are like "Oh, you go to a [state college]?" She says she gets that a lot, especially from Asian American communities. She says, growing up, people would make fun of her a lot.

These experiences served a socializing function that communicated what were acceptable and unacceptable vocational choices for Asian Americans and were communicated by both Asian American and non-Asian American peers.

\section{DISCUSSION}

The objective of this study was to explore how Asian American college students' career choices may be influenced by their intersecting identities as students of color and as members of the new immigrant second generation. The four themes that emerged included: (a) family desires, (b) perceived labor market inequalities, (c) racial isolation in atypical fields, and (d) peer networks. Through their experiences at home and on campus with parents, family, friends, and classmates, Asian American students in this study confronted social pressures that valued the pursuit of careers in STEM and other fields with perceived financial rewards. Faced with these expectations, many Asian American students in this study learned to navigate social pressures and personal vocational interests to pursue atypical pathways.

This study demonstrated that, for some Asian American students, career choice considerations include more than personal interests or even familial expectations. Instead, complex racialized immigrant experiences shaped the social contexts within which Asian 
Americans can make career choices. Racial microaggressions and other social interactions reinforced dominant racial narratives and stereotypes, produced by a sociohistorical context of racial formation and immigration history (Lee, 2006; Omi \& Winant, 1994).

As with past research, this study found that family influences can play an important role in students' academic and career choices, encouraging study participants to pursue occupational pathways perceived to bring financial gains. Unlike past studies, this project did not focus on the correlation between acculturation and the likelihood of Asian Americans choosing atypical careers. Findings suggested that immigrant families serve as an important social context for Asian American career choices. Through family interactions, expectations laden with concerns related to immigrant incorporation and desires of upward mobility were communicated to students in the study.

Providing possible explanations for their immigrant parents' expectations and perceptions, some interview participants, such as Amber, suggested that their parents' experiences of immigration, poverty, and inequalities create an important context for understanding. According to Maramba (2008), many Asian American college students are confronted by the challenge of negotiating between home/ family and college environments, juggling the obligations and expectations of each of these spaces. Thus, while Chickering and Reisser (1993) argued that "moving through autonomy toward interdependence" is a key developmental task for college students, for some Asian American college students career choices can represent an important decision that is potentially laden with complex social consequences and implications.

Perceptions of racism, in addition to family preferences shaped by the immigrant experience, were also found to affect Asian
American college student career choices. For some Asian American students, stereotypes, a lack of co-ethnic role models in atypical career paths, and perceived discrimination in labor markets created obstacles to pursuing their interests. Some of the interview participants reasoned that the underrepresentation of Asian Americans in certain fields, such as entertainment, the arts, and design, denoted barriers to entry and advancement for Asian Americans. Moreover, some described uneasiness over being the "only one" or one of only a few Asian Americans in their fields that interestingly mirrored the racially isolating experiences researchers have identified as characteristic for other minority students (Syed, Azmitia, \& Cooper, 2011).

Peer networks also maintained and reinforced the message and dominant racial script that Asian Americans are meant to pursue STEM fields and other areas perceived to reap financial reward. In addition to perpetuating dominant Asian American occupational pursuits, peer networks reinforced financial concerns conveyed by immigrant families of some of the participants. Asian American peers who reinforced dominant occupational choices may have been expressing a level of internalized racism, which perpetuates established racial meanings and can be a reaction to oppressive social forces (Pyke \& Dang, 2003). This might suggest that racial microaggressions can be enacted by students of color toward coethnics, complicating current concepts of racial microaggressions.

\section{Implications for Student Affairs Practitioners}

The study's findings suggest a number of ways to better serve diverse Asian American college students. As a population that is generally reluctant to seek counseling services, Asian American students might be more open to career exploration activities (Leong \& Serafica, 1995), which provide pathways for 
student services professionals to reach out to this population. Only two of the students in this study said they had ever visited Coastal University's Career Center, highlighting the importance of family and social networks as information sources for Asian American students and the need for intentional outreach efforts and targeted programming by academic and career counseling services.

In response to the importance of family in Asian American career decision making, campuses might consider developing programs that expose families of Asian American students to the broad range of academic and career opportunities available. Many Asian American students are first-generation college goers with parents who are unfamiliar with the mission of U.S. higher education and resources and opportunities available in college (Chang et al., 2007). As parent programs expand to facilitate the involvement of mostly college-educated "helicopter parents" (Lum, 2006), institutional leaders should consider helping parents of first-generation college students to become informed partners in their children's education.

To address concerns among Asian Americans over discrimination, economic instability, or the lack of role models in atypical fields, student services programs might consider partnering with alumni services offices to develop mentoring programs or dialogues. Through these initiatives, students may be exposed to different career possibilities and ask Asian American alumni about their experiences as well as receive advice about pursuing different careers and even mentorship on negotiating potential conflicts between family expectations and personal interests from co-ethnic role models.

\section{Limitations, Future Research, and Conclusion}

Overall, it is imperative for educators to become more knowledgeable about the lived experiences of Asian American students, which is an underresearched and underserved yet growing population in higher education. Asian American career development is one area that requires more research attention. Although individual interest and personality types have been identified as important factors shaping career development, for Asian Americans external and social variables can also play significant roles in shaping their choices.

There are key limitations to this study of which to be aware. First, student responses might have been biased by presenting students with a description of racial microaggressions at the beginning of interviews. Second, because this project used a pan-ethnic lens, it was not possible to legitimately comment on differences by ethnicity. Moreover, the number of participants did not allow for a solid analysis of ethnic difference. Finally, the study did not explicitly include a gender lens. However, at least two of the interviewed students suggested that gender affected their experiences in career decision making.

Challenges presented by the students in this study may seem innocuous, given that the occupational patterns for college educated Asian Americans can lead to middle-class status. However, understanding these experiences as outcomes of social processes, such as racial formation and immigrant adaptation, can lead to more complex knowledge about how race operates in students' lives and the incorporation of the new second generation through vocational choices. Future research could determine whether patterns and processes of Asian American career development and choice can lead to negative outcomes in academic progress, family conflicts, emotional and mental health, and other areas of development. Also, although an emerging field of research has sought to understand and improve upon the underrepresentation of non-Asian minorities in STEM fields (Hurtado et al., 
2007, 2011; Hurtado, Cabrera, Lin, Arellano, \& Espinosa, 2009), few studies have conversely investigated the underrepresentation of Asian Americans in non-STEM fields such as education (Teranishi, 2010).

In conclusion, this study challenged the assumption that Asian Americans are moving smoothly along an upwardly mobile path of immigrant adaptation and the idea that the United States provides unlimited choice in determining career goals. Prevailing stereotypes of Asian Americans as monolithically successful and industrious may lead to an assumption that these students require less support than other students, even though many are firstgeneration college students from low-income and immigrant or refugee families (Chang et al., 2007; Suzuki, 2002; Yeh, 2002). More in-depth analysis can reveal complex processes at play that influence, challenge, and support Asian American student development.

Correspondence concerning this article should be addressed to OiYan Poon, Loyola University Chicago School of Education, 820 N. Michigan Ave., Lewis Towers 1152, Chicago, IL 60611; opoon@luc.edu

\section{REFERENCES}

Brint, S., Douglass, J. A., Flacks, R., Thomson, G., \& Chatman, S. (2007). A new generation: Ethnicity, socioeconomic status, immigration and the undergraduate experience at the University of California (No. CSHE.14.07). Research and Occasional Papers Series. Berkeley, CA: Center for Studies in Higher Education.

Brown, S. C. (2004). Where this path may lead: Understanding career decision-making for postcollege life. Journal of College Student Development, 45, 375-390.

Chan, S. (1991). Asian Americans: an interpretive history. Farmington Hills, MI: Twayne.

Chang, M. J., Park, J. J., Lin, M. H., Poon, O. A., \& Nakanishi, D. T. (2007). Beyond myths: The growth and diversity of Asian American college freshmen, 1971-2005. Los Angeles, CA: UCLA Higher Education Research Institute.

Chickering, A. W., \& Reisser, L. (1993). Education and identity (2nd ed.). San Francisco, CA: Jossey-Bass.

Creswell, J. W., \& Miller, D. L. (2000). Determining validity in qualitative inquiry. Theory into Practice, 39(3), 124-130.

Delgado Bernal, D. (1998). Using a Chicana feminist epistemology in educational research. Harvard Educational Review, 68, 555-583.

Evans, N. J., Forney, D. S., \& Guido-DiBrito, F. (1998). Student development in college: Theory, research and application. San Francisco, CA: Jossey-Bass.

Feldman, K. A., Smart, J. C., \& Ethington, C. A. (2004). What do college students have to lose? Exploring the outcomes of differences in person-environment fits. Journal of Higher Education, 75(5), 528-555.

Glaser, B. G. (2002). Conceptualization: On theory and theorizing using grounded theory. International Journal of Qualitative Methods, 1(2), 23-38.

Hing, B. O. (2004). Defining America through immigration policy. Philadelphia, PA: Temple University Press.
Holland, J. L. (1997). Making vocational choices: A theory of vocational personalities and work environments (3rd ed.). Odessa, FL: Psychological Assessment Resources.

Hurtado, S., Cabrera, N., Lin, M., Arellano, L., \& Espinosa, L. (2009). Diversifying science: Underrepresented student experiences in structured research programs. Research in Higher Education, 50, 189-214.

Hurtado, S., Eagan, M. K., Tran, M. C., Newman, C. B., Chang, M. J., \& Velasco, P. (2011). "We Do Science Here": Underrepresented students' interactions with faculty in different college contexts. Journal of Social Issues, 67, 553-579.

Hurtado, S., Han, J. C., Sáenz, V. B., Espinosa, L. L., Cabrera, N. L., \& Cerna, O. S. (2007). Predicting transition and adjustment to college: Biomedical and behavioral science aspirants' and minority students' first year of college. Research in Higher Education, 48, 841-887.

Kauanui, J. K. (2008, September 8). Where are Native Hawaiians and other Pacific Islanders in higher education? [Blog post]. Retrieved from http://diverseeducation .wordpress.com/2008/09/08/where-are-native-hawaiiansand-other-pacific-islanders-in-higher-education/

Kim, C. J. (1999). The racial triangulation of Asian Americans. Politics Society, 27(1), 105-138.

Kodama, C. M., McEwen, M. K., Liang, C. T. H., \& Lee, S. (2001). A theoretical examination of psychosocial issues for Asian Pacific American students. NASPA Journal, 38, 411-437.

Lee, S. S. (2006). Over-represented and de-minoritized: The racialization of Asian Americans in higher education. InterActions: UCLA Journal of Education and Information Studies, 2(2), Article 4. Retrieved from http://escholarship .org/uc/item/4r7161b2

Leong, F. T. L., \& Chou, E. L. (1994). The role of ethnic identity and acculturation in the vocational behavior of Asian Americans: An integrative review. Journal of Vocational Behavior, 44, 155-172. 
Leong, F. T. L., Kao, E. M., \& Lee, S. (2004). The relationship between family dynamics and career interests among Chinese Americans and European Americans. Journal of Career Assessment, 12(1), 65-84.

Leong, F. T. L., \& Serafica, F. C. (1995). Career development of Asian Americans: A research area in need of a good theory. In F. T. L. Leong (Ed.), Career development and vocational behavior of racial and ethnic minorities (pp. 67-102). Mahwah, NJ: Lawrence Erlbaum Associates.

Lowe, L. (1996). Immigrant acts: On Asian American cultural politics. Durham, NC: Duke University Press.

Lum, L. (2006,). Handling 'helicopter parents,' Diverse Issues in Higher Education. Retrieved from http://diverseeducation. com/article/6657/

Maramba, D. C. (2008). Immigrant families and the college experience: Perspectives of Filipina Americans. Journal of College Student Development, 49, 336-350.

McEwen, M. K., Kodama, C. M., Alvarez, A. N., Lee, S., \& Liang, C. T. H. (2002). Editors' notes. In M. K. McEwen, C. M. Kodama, A. N. Alvarez, S. Lee, \& C. T. H. Liang (Eds.), New Directions for Student Services, No. 97: Special issue: Working with Asian American college students (pp. 1-4). San Francisco, CA: Jossey-Bass.

Museus, S. D., \& Kiang, P. N. (2009). Deconstructing the model minority myth and how it contributes to the invisible minority reality in higher education research. In S. D. Museus (Ed.), New Directions for Institutional Research, No. 142: Conducting research on Asian Americans in higher education (pp. 5-15). San Francisco, CA: Jossey-Bass.

Omi, M., \& Winant, H. (1994). Racial formation in the United States: From the 1960s to the 1990s (2nd ed.). New York, NY: Routledge.

Ong, P. M., \& Liu, J. M. (1994). Pacific Rim development and the duality of post-1965 Asian immigration to the United States. In P. M. Ong \& E. Bonacich (Eds.), The new Asian immigration in Los Angeles and global restructuring (pp. 45-73). Philadelphia, PA: Temple Press.

Park, L. S. (2005). Consuming citizenship: Children of Asian immigrant entrepreneurs. Palo Alto, CA: Stanford University Press.

Patel, S. G., Salahuddin, N. M., \& O’Brien, K. M. (2008). Career decision-making self-efficacy of Vietnamese adolescents. Journal of Career Development, 34(3), 218-240.

Patton, M. Q. (2002). Two decades of developments in qualitative inquiry: A personal, experiential perspective. Qualitative Social Work, 1, 261-283.

Portes, A., \& Fernández-Kelly, P. (2008). No margin for error: Educational and occupational achievement among disadvantaged children of immigrants. Annals of the American Academy of Political and Social Science, 620(1), 12-36.

Portes, A., \& Rumbaut, R. G. (2001). Legacies: The story of the immigrant second generation. Berkeley, CA: University of California Press.
Portes, A., \& Rumbaut, R. G. (2006). Immigrant America: A portrait. Berkeley, CA: University of California Press.

Pyke, K., \& Dang, T. (2003). "FOB" and "whitewashed": Identity and internalized racism among second generation Asian Americans. Qualitative Sociology, 26, 147-172.

Roysircar, G., Carey, J., \& Koroma, S. (2010). Asian Indian college students' science and math preferences: Influences of cultural contexts. Journal of Career Development, 36, 324-347.

Solórzano, D. G. (1998). Critical race theory, race and gender microaggressions, and the experience of Chicana and Chicano scholars. International Journal of Qualitative Studies in Education, 11(1), 121-136.

Solórzano, D. G., Allen, W. R., \& Carroll, G. (2002). Keeping race in place: Racial microaggressions and campus racial climate at the University of California, Berkeley. ChicanoLatino Law Review, 23(15), 15-112.

Suárez-Orozco, C., \& Suárez-Orozco, M. M. (2001). Children of immigration. Cambridge, MA: Harvard University Press.

Sue, D. W., Bucceri, J., Lin, A. I., Nadal, K. L., \& Torino, G. C. (2007). Racial microaggressions and the Asian American experience. Cultural Diversity and Ethnic Minority Psychology, 13(1), 72-81.

Suzuki, B. H. (2002). Revisiting the model minority stereotype: Implications for student affairs practice and higher education. In M. K. McEwen, C. M. Kodama, A. N. Alvarez, S. Lee, \& C. T. H. Liang (Eds.), New Directions for Student Services, No. 97: Special issue: Working with Asian Americn college students (21-32). San Francisco, CA: Jossey-Bass.

Syed, M., Azmitia, M., \& Cooper, C. R. (2011). Identity and academic success among underrepresented ethnic minorities: An interdisciplinary review and integration. Journal of Social Issues, 67, 442-468.

Takaki, R. T. (1989). Strangers from a different shore: a history of Asian Americans. New York, NY: Penguin Books.

Tang, M., Fouad, N. A., \& Smith, P. L. (1999). Asian Americans' career choices: A path model to examine factors influencing their career choices. Journal of Vocational Behavior, 54, 142-157.

Teranishi, R. T. (2010). Asians in the ivory tower: Dilemmas of racial inequality in American higher education. New York, NY: Teachers College Press.

Yeh, T. L. (2002). Asian American college students who are educationally at risk. In M. K. McEwen, C. M. Kodama, A. N. Alvarez, S. Lee, \& C. T. H. Liang (Eds.), New Directions for Student Services, No. 97: Special issue: Working with Asian American college students (pp. 61-72). San Francisco, CA: Jossey-Bass.

Yosso, T. J. (2006). Critical race counterstories along the Chicanal Chicano educational pipeline. New York, NY: Routledge. 